\title{
KEPUASAN PESERTA DIKLAT TERHADAP PELAYANAN WIDYAISWARA
}

\author{
Agus Akhmadi \\ Badan Penelitian dan Pengembangan dan Pendidikan dan Pelatihan - Kementerian Agama \\ Email: agusakhmadi63@gmail.com \\ https://doi.org/10.36052/andragogi.v7i2.101 \\ Diterima: 24 Oktober 2019 | Disetujui: 2 Desember 2019 | Dipublikasikan: 30 Desember 2019
}

\begin{abstract}
Abstrak
Penelitian ini bertujuan untuk mendapatkan data tentang kepuasan peserta diklat terhadap layanan kediklatan widyaiswara Balai Pendidikan dan Pelatihan Keagamaan Surabaya. Penelitan ini menggunakan pendekatan kuantitatif dengan metode survei untuk mengetahui faktor-faktor kepuasan peserta diklat. Instrumen pengumpulan data menggunakan kuesioner yang diberikan kepada alumni Diklat Substantif Bimbingan dan Konseling Madrasah Aliyah tahun 2019. Instrumen tersebut meliputi dimensi tangibles, reliability, responsiveness, assurance dan empathy widyaiswara. Hasil penelitian menunjukkan bahwa layanan kediklatan yang dilakukan Widyaiswara Balai Diklat Keagamaan Surabaya telah memenuhi aspek tangible (penampilan fisik serta kondisi pelayanan widyaiswara), keandalan (kompetensi diklat yang dijanjikan dengan akurat dan terpercaya sesuapi harapan peserta), respon (bijaksana memberikan layanan cepat kepada peserta), assuransi (kemampuan melaksanakan tugas secara spontan yang menjamin kualitas diklat), dan empati (memberikan perhatian individual dan memahami peserta diklat). Kualitas rata-rata dan keseluruhan aspek telah menunjukkan nilai sangat memuaskan. Urutan kualitas paling memuaskan adalah pada dimensi: empati, assuranse, tangible, keandalan, dan respon widyaiswara dalam diklat.
\end{abstract}

Kata Kunci: kepuasan, kualitas pelayanan, widyaiswara

\begin{abstract}
This study aims to obtain data on training participants' satisfaction with the widyaiswara education service at Balai Diklat Keagamaan Surabaya. This research uses a quantitative approach with a survey method to find out the training participants' satisfaction factors. Data collection instruments used a questionnaire given to alumni of the 2019 Madrasah Aliyah Guidance and Counseling for Madrasah Aliyah. These instruments included tangibles, reliability, responsiveness, assurance and empathy widyaiswara dimensions. The results showed that the training services conducted by Widyaiswara Balai Diklat Keagamaan Surabaya have fulfilled tangible aspects (physical appearance and widyaiswara service conditions), reliability (training competence promised accurately and reliably according to participants' expectations), response (wise providing fast service to participants), insurance (the ability to carry out tasks spontaneously that guarantees the quality of training), and empathy (giving individual attention and understanding of training participants). The average quality and overall aspects have shown very satisfying value. The most satisfying quality sequences are on the dimensions: empathy, assurances, tangible, reliability, and widyaiswara responses in training.
\end{abstract}

Keywords: satisfaction, service quality, widyaiswara 


\section{PENDAHULUAN}

$\mathscr{P}$

roses pendidikan dan latihan merupakan aktivitas yang berusaha untuk mentransfer ilmu pengetahuan, sikap, dan keterampilan kepada peserta diklat. Pendidikan dan Pelatihan dikategorikan sebagai layanan jasa, karena peserta diklat mendapatkan manfaat dari produk kediklatan (Nuraini, 2018).

Konsep kepuasan masyarakat atau pengguna produk atau jasa, adalah sikap penilaian evaluatif purna konsumsi yang bervariasi berdasarkan kontinum hedonis. Kepuasan adalah fenomena rangkuman atribut bersama-sama dengan emosi konsumsi lainnya. Kepuasan dikonseptualisasikan sebagai perasaan yang timbul setelah mengevaluasi pengalaman pemakaian produk (Cadotte, 1987). Kepuasan juga sebagai perasaan senang atau kecewa yang timbul karena membandingkan kinerja yang dipersepsikan hasil terhadap ekspektasi mereka (Keller, 2008).

Berdasarkan beberapa definisi kepuasan pelanggan, maka dapat disimpulkan bahwa kepuasan pelanggan merupakan evaluasi keseluruhan purnabeli yang dapat dipersepsikan dengan perasaan senang atau kecewa setelah membandingkan kinerja produk dengan standar pembelian. Kepuasan tergantung pada banyak faktor, terutama hubungan loyalitas yang dimiliki pelanggan dengan sebuah merek produk (Kotler \& Kevin, 2008).

Dalam model kualitas pelayanan yang mempertimbangkan fungsi produksi, maka jika pengalaman terbukti lebih baik dari harapan maka akan menciptakan kepuasan atau kualitas yang tinggi (Ariani, 2009).
Kepuasan

cenderung

berhubungan dengan hasil ekspresif yang berada di atas atau sama dengan harapan sedangkan ketidakpuasan akan cenderung berhubungan dengan kinerja dibawah harapan. Faktor yang menimbulkan kepuasan terhadap produk adalah terpenuhinya harapan terhadap hasil ekspresif dan instrumental (Ariani, 2009).

Dalam proses pendidikan dan pelatihan, terdapat proses interaksi yang aktif antara peserta diklat dengan Widyaiswara, interaksi dua arah secara aktif agar terjadi transfer ilmu, sikap, dan keterampilan secara optimal. Proses transfer pengetahuan, sikap dan keterampilan tersebut memerlukan komunikasi dan interaksi.

Dalam proses kediklatan, Widyaiswara dalam melakukan proses belajar mengajar memerlukan kondisi yang memadai berupa kemampuan widyaiswara. Selain itu peserta diklat juga akan mempunyai pengalaman belajar selama mengikuti diklat. Perasaan dan persepsi peserta diklat terhadap Widyaiswara selama mengikuti diklat terangkum dalam rasa kepuasan peserta diklat, yaitu rasa puas dan tidak puas.

Widyaiswara berperan untuk meningkatkan pelayanan pendidikan dan pelatihannya, agar tingkat kepuasan peserta diklat memadai. Peran tersebut harus dilakukan widyaiswara dengan meningkatkan kompetensi kediklatan yang dibutuhkan sesuai dengan spesialisasinya.

Kepuasan peserta diklat dalam proses kediklatan sangat bergantung pada widyaiswara, proses kediklatan yang sesuai harapan peserta diklat 
merupakan cerminan dari kompetensi widyaiswara dalam melaksanakan diklat.

Kompetensi widyaiswara seringkali terkait dengan kualitas layanan kediklatannya. Semakin kompeten Widyaiswara, diharapkan semakin berkualitas proses kediklatannya dan ini akan membuat peserta diklat merasa puas. Kepuasan sering dimaknai dengan kualitas, dan suatu produk dikatakan berkualitas apabila dapat memberi kepuasan sepenuhnya kepada konsumen, yaitu sesuai dengan apa yang diharapkan konsumen atas suatu produk.

Produk kediklatan adalah layanan widyaiswara yang merupakan cerminan dari kompetensinya, sedangkan konsumen adalah peserta diklat yang merasakan kinerja dari widyaiswara berdasarkan kompetensi standar yang telah dimilikinya. Kepuasan peserta diklat merupakan sikap, penilaian dan respon emosional yang ditunjukkan oleh pelanggan setelah proses penggunaan layanan yang berasal dari perbandingan kesan-nya terhadap kinerja aktual suatu produk/jasa dan harapannya.

Lembaga diklat harus mampu menawarkan kualitas produk atau jasa dalam rangka menciptakan kepuasan pelanggan. Peserta diklat merupakan subyek utama kepuasan dan kualitas jasa/ layanan kediklatan, oleh karena itu, peserta diklat dijadikan sumber untuk mengukur kepuasan pelayanan widyaiswara Balai Diklat Keagamaan Surabaya.

Lembaga pendidikan dan pelatihan menaruh perhatian kepada kepuasan peserta disebabkan kunci utama untuk memenangkan persaingan adalah memberikan nilai kepuasan pelanggan melalui penyampaian produk/jasa yang berkualitas dengan biaya bersaing. Lembaga harus mengetahui pergeseran kebutuhan dan keinginan pelanggan yang setiap saat berubah. Karena kepuasan pelanggan sangat tergantung pada harapan pelanggan, maka sebagai pemasok produk atau jasa perlu mengetahui faktor-faktor yang mempengaruhinya.

Kemampuan memberikan kepuasan harus ada pada widyaiswara melalui proses kegiatan diklat yang berjalan lancar dan hasil diklat yang bermutu. Mutu kediklatan merupakan kebutuhan yang menjadi keharusan dalam meningkatkan sumberdaya manusia di lingkungan Kementerian Agama.

Kepuasan pelanggan memang sulit diukur secara langsung namun hal ini dapat dilihat dari berbagai macam persepsi pelanggan. Kepuasan merupakan tingkat perasaan dimana seseorang menyatakan hasil perbandingan atas kinerja produk (jasa) yang diterima dan yang diharapkan oleh pelanggan (Lupiyoadi \& Hamdani, 2006).

Tingkat kepuasan pelanggan yang tinggi akan dapat menciptakan loyalitas pelanggan dan mencegah perputaran pelanggan, mengurangi sensitivitas pelanggan terhadap harga, mengurangi biaya kegagalan pemasaran, mengurangi biaya operasi yang diakibatkan oleh meningkatnya jumlah pelanggan, meningkatkan efektivitas iklan, dan meningkatkan reputasi.

Kepuasan dan ketidakpuasan pelanggan dapat berakibat pada perilaku pelanggan selanjutnya. Jika pelanggan puas terhadap suatu layanan maka akan melakukan pembelian ulang. Kepuasan dipengaruhi oeh kualitas 
layanan. Kualitas layanan suatu lembaga dipengaruhi 1). Faktor kualitas interaksi, Kualitas interaksi ditentukan oleh sikap, perilaku dan keahlian. 2). Kualitas lingkungan fisik. Kualitas lingkungan fisik dipengaruhi oleh ambient conditions, desain, faktor sosial. 3) Kualitas hasil. Kualitas hasil dipengaruhi waku tunggu, faktor fisik dan valensi (Nuraini, 2018).

Kualitas pelayanan menurut Zeithaml dan Bitner, dalam (Nuraini, 2018) terdapat lima dimensi kualitas pelayanan yang dijadikan pedoman oleh pelanggan atau peserta dalam menilai kualitas pelayanan, yaitu:

1). Bukti fisik atau bukti langsung (tangibles). Penampilan sarana dan prasarana fisik serta keadaan lingkungan sekitarnya adalah bukti nyata dari pelayanan yang diberikan oleh pemberi jasa. Dalam layanan kediklatan yang diberikan widyaiswara, dimensi ini adalah hal-hal terkait dengan penampilan widyaiswara, media pembelajaran yang digunakan, kemampuan widyaiswara dalam memberikan contoh-contoh.

2) Keandalan (reliability). Keandalan adalah kompetensi widyaiswara untuk memberikan jasa layanan yang dijanjikan dengan akurat dan terpercaya, kinerja ini sesuai dengan harapan peserta seperti ketepatan waktu, pelayanan yang adil dan tanpa kesalahan. Dimensi keandalan dalam diklat juga terkait dengan pelayanan yang diberikan widyaiswara seperti penguasaan materi, ketepatan menggunakan metode dan teknik mengajar, pengelolaan kelas dan ketercapain tujuan.

3) Daya Tanggap (responsivenes). Responsiv merupakan kebijaksanaan untuk memberikan layanan yang cepat kepada peserta diklat, tidak membiarkan peserta menunggu tanpa adanya suatu alasan yang jelas yang menyebabkan persepsi yang negatif dalam kualitas pelayanan. Dalam diklat, widyaiswara membantu peserta dan tanggap dalam merespon peserta, tanggap akan keluhan peserta diklat atau dalam menyajikan materi dalam bekerja tanpa menunggu peserta diklat berfikir negatif terhadap layanan yang diberikan.

4) Jaminan (assurance). Jaminan merupakan kemampuan melaksanakan tugas secara spontan yang dapat menjamin kinerja yang baik sehingga menimbulkan kepercayaan dan keyakinan peserta diklat. Widyaiswara yang memiliki assurance mampu memberikan keyakinan dan kepercayaan peserta akan proses dan hasil diklat, disiplin dalam jadwal kegiatan, menilai peserta secara obyektif.

5) Empati (emphaty). Empati merupakan kemampuan memberikan perhatian individual dan berupaya untuk memahami peserta. Widyaiswara memberikan kemudahan berinteraksi secara pribadi dan berupaya untuk memahami peserta, mampu memotivasi peserta dan memperlakukan peserta secara adil.

Berdasarkan definisi dan dimensi layanan diatas dapat disimpulkan bahwa kepuasan peserta diklat merupakan sikap, penilaian dan respon emosional yang ditunjukkan oleh peserta diklat setelah proses layanan dengan cara memperbandingkan kesannya terhadap kinerja aktual kediklatan dengan harapannya.

Penelitian ini merupakan survei tentang kepuasan layanan diklat subtantif guru Bimbingan dan Konseling Madrasah Aliyah Jawa Timur di Balai 
Diklat Keagamaan Surabaya. Masalah yang disurvei adalah kepuasan peserta diklat terhadap layanan widyaiswara dalam layanan kediklatan, mencakup aspek: bukti langsung kinerja widyaiswara, keandalan, responsivitas, jaminan, dan empati.

Tujuan dari penelitian ini adalah untuk mengetahui faktor kepuasan peserta diklat guru BK Madrasah Aliyah terhadap layanan widyaiswara.

Manfaat dari penelitian survei ini adalah mendapatkan data tentang factor kepuasan layanan widyaiswara Balai Diklat Keagamaan Surabaya dalam melaksanakan layanan kediklatan.

\section{METODE PENELITIAN}

Metode yang digunakan dalam penelitian ini adalah survei deskriptif kuantitatif dengan cara mendeskripsikan dimensi kepuasan peserta diklat dalam mengikuti diklat. Peneliti mengumpulkan data kepuasan peserta diklat terhadap layanan widyaiswara. Alur dan tahapan penelitian yang dilakukan adalah sebagai berikut:

Tabel 1 Tahapan Penelitian

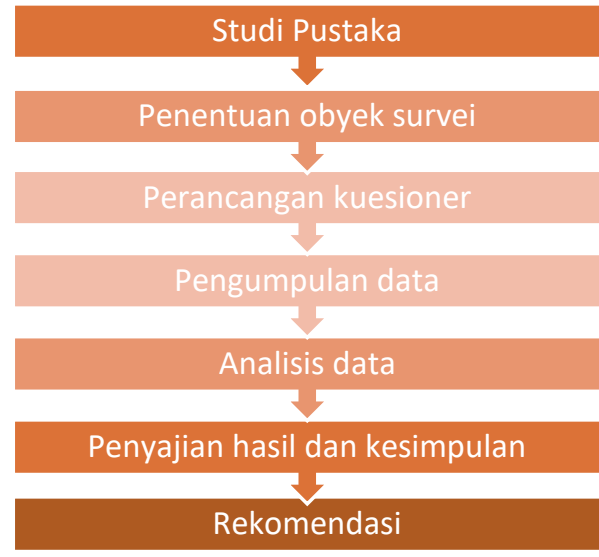

Penelitian dimulai dengan mengkaji konsep kepuasan layanan diklat. Berdasarkan tinjauan pustaka, diambil variabel dimensi kepuasan layanan diklat. Berdasarkan faktor kepuasan layanan diklat, ditentukan indikator kepuasan layanan sesuai peran widyaiswara.

Indikator-indikator penelitian yang digunakan dalam survei kepuasan layanan widyaiswara adalah sebagai berikut:

Tabel 2 Indikator Penelitian

\begin{tabular}{|c|c|c|}
\hline No & Variabel & Indikator \\
\hline 1. & $\begin{array}{l}\text { Bukti nyata/ } \\
\text { Tangibles }\end{array}$ & $\begin{array}{l}\text { Kemampuan } \\
\text { widyaiswara } \\
\text { kediklatan }\end{array}$ \\
\hline 2. & $\begin{array}{l}\text { Keandalan/ } \\
\text { Reliability }\end{array}$ & $\begin{array}{l}\text { Penguasaan materi, } \\
\text { ketepatan } \\
\text { menggunakan metode } \\
\text { dan teknik mengajar, } \\
\text { pengelolaan kelas dan } \\
\text { ketercapain tujuan. }\end{array}$ \\
\hline 3. & $\begin{array}{l}\text { Daya } \\
\text { tanggap/ } \\
\text { Responsiven } \\
\text { ess }\end{array}$ & $\begin{array}{ll}\text { Merespon } & \text { peserta, } \\
\text { tanggap akan keluhan } \\
\text { peserta diklat }\end{array}$ \\
\hline 4. & $\begin{array}{l}\text { Wujud } \\
\text { Jaminan/ } \\
\text { Insurences }\end{array}$ & $\begin{array}{l}\text { Memberikan keyakinan } \\
\text { dan kepercayaan } \\
\text { peserta akan proses } \\
\text { dan hasil diklat, disiplin } \\
\text { kegiatan, obyektif. }\end{array}$ \\
\hline 5. & Empati & $\begin{array}{l}\text { Memberikan perhatian } \\
\text { individual dan } \\
\text { memahami peserta }\end{array}$ \\
\hline
\end{tabular}

Berdasarkan indikator tersebut, selanjutnya disusun menjadi kuesioner penelitian. Kuesioner selanjutnya dimasukkan dalam aplikasi google formulir. Sasaran penelitian ini adalah alumni diklat teknis subtantif guru Bimbingan dan Konseling Madrasah Aliyah Jawa Timur, sejumlah 35 orang, yang diselenggarakan pada bulan Agustus 2019. Hasil isian responden yang tersajikan di unggahan google formulir selanjutnya diunduh dalam 
bentuk frekwensi data yang siap dianalisa.

1. Instrumen Penelitian

Pengumpulan data persepsi alumni diklat guru BK tentang kepuasan layanan widyaiswara dilakukan dengan menggunakan kuesioner. Berdasarkan permasalahan dan indikator penelitian, maka dimensi kepuasan layanan pembelajaran widyaiswara adalah: Tangible, Keandalan, Responsiv, Jaminan dan empati (Nuraini, 2018). Skala angket memiliki rentang 1 - 5 .

Tabel 3 Skala jawaban angket

\begin{tabular}{llc}
\hline No & Alternatif Jawaban & Kategori \\
\hline 1 & Sangat tidak & 1 \\
& memuaskan & \\
2 & Tidak memuaskan & 2 \\
3 & Kurang memuaskan & 3 \\
4 & Memuaskan & 4 \\
5 & Sangat memuaskan & 5 \\
\hline
\end{tabular}

Selanjutnya dimensi tersebut diurai menjadi butir pertanyaan, butir angket yang telah disiapkan, diubah dalam aplikasi google formulir dan diunggah serta disebarkan ke seluruh alumni diklat guru BK Madrasah Aliyah. Pengumpulan data penelitian dilaksanakan mulai bulan Agustus 2019 sampai dengan September 2019.

2. Populasi dan Sampel

Survei dilaksanakan terhadap alumni diklat Teknis Subtanstif Bimbingan dan Konseling Guru BK Madrasah Aliyah Jawa Timur, yang dilaksanakan bulan Agustus 2019. Semuanya menjadi populasi atau subyek, yaitu sebanyak 35 orang.
Teknik ini termasuk teknik sampling jenuh atau sensus karena semua anggota populasi digunakan sebagai sampel.

3. Teknik dan Instrumen Penelitian

Pada penelitian ini, pengumpulan data dilakukan dengan menggunakan kuesioner yang dimanfaatkan untuk mengambil data kepuasan peserta diklat terhadap layanan kediklatan Widyaiswara.

Data yang masuk dianalisis dengan menggunakan analisis desktiptif dengan menyajikan distribusi frekuensi dan mean masing-masing item variabel dan aspek. Untuk mendeskripsikan nilai mean setiap variabel dan aspek dalam penelitian ini digunakan dengan interval kelas.

Nilai skor jawaban responden dalam penelitian ini mengacu pada skala 5 poin dari Likert, sehingga nilai skor jawaban responden tertinggi adalah 5 dan untuk nilai skor terendah adalah 1, sedangkan jumlah kelas/kategori yang digunakan dalam penyusunan kriteria tersebut disesuaikan dengan skala yang digunakan yaitu 5 kelas. Sehingga interval yang diperoleh untuk setiap kelas (5-1): $5=0,8$.

Kriteria untuk mendeskripsikan nilai mean yang diperoleh setiap variabel dan aspek dapat disusun seperti berikut:

Tabel 4. Nilai Skor dan Kategori

\begin{tabular}{lll}
\hline No & Skor & Kategori \\
\hline 1 & $1,00-1,80$ & Tidak memuaskan \\
2 & $1,90-2,60$ & Kurang \\
& & memuaskan \\
3 & $2,70-3,40$ & Cukup \\
\hline
\end{tabular}




\begin{tabular}{lll} 
& & memuaskan \\
4 & $3,50-4,20$ & Memuaskan \\
5 & $4,30-5,00$ & Sangat \\
& & memuaskan \\
\hline
\end{tabular}

\section{TEMUAN DAN PEMBAHASAN}

\section{Temuan}

Responden yang berpartisipasi dalam penelitian ini adalah guru BK MA alumni diklat tahun 2019. Alumni diklat diberikan kuesioner melalui internet sesuai alamat WhatsApp guru BK masing-masing dalam bentuk google formulir.

Dari kuesioner yang diunggah, yang menyelesaikan kuesioner dan mengirim kembali instrumen berjumlah 31 peserta. Data responden penelitian ini adalah sebagai berikut:

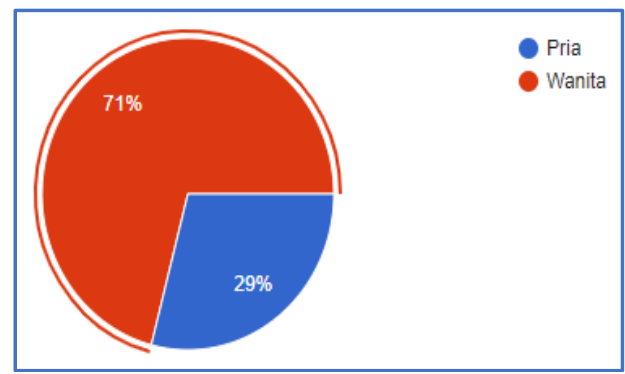

Grafik 1. Jenis Kelamin Responden

Data tersebut menunjukan $71 \%$ responden penelitian ini adalah guru BK wanita dan $29 \%$ responden adalah guru BK laki-laki.

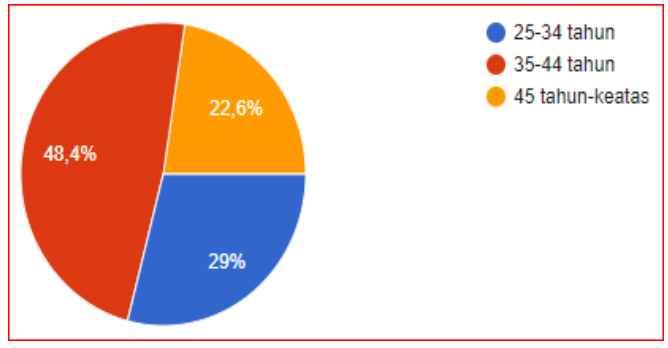

Grafik 2. Usia Responden
Data pada Grafik 2 menunjukan sebanyak 29 \% responden guru BK berusia muda antara umur 25 sampai 34 tahun, $43 \%$ responden adalah guru BK berusia antara umur 35 sampai 44 tahun, dan $22 \%$ responden guru BK berusia 45 keatas.

Data pada Grafik 3 menunjukan sebanyak $90,3 \%$ responden adalah guru BK berpendidikan Strata 1, dan 9,3\% responden adalah guru BK berpendidikan strata 2 .

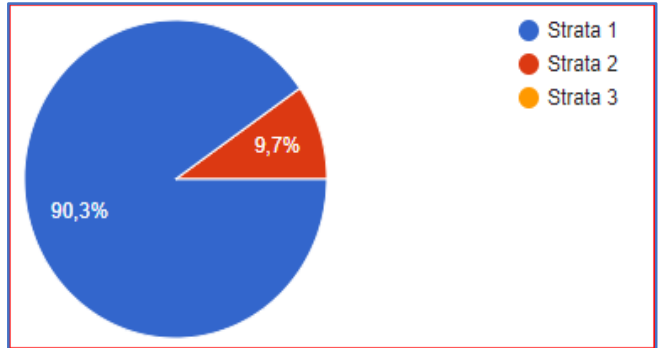

Grafik 3. Pendidikan Responden

Temuan penelitian tentang kepuasan peserta diklat terhadap layanan widyaiswara dalam diklat guru Bimbingan dan Konseling Madrasah Aliyah tahun 2019 adalah sebagaimana Grafik 4.

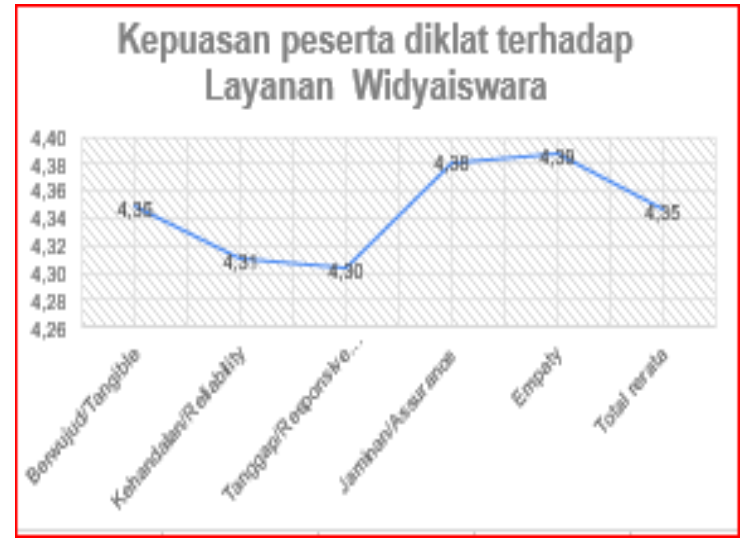

Grafik 4. kepuasan peserta diklat terhadap layanan widyaiswara dalam diklat

Dalam layanan kediklatan yang diberikan widyaiswara, dimensi 
kepuasan meliputi hal-hal terkait dengan kemampuan yang langsung dilakukan widyaiswara dalam pembelajaran berupa tangible, keandalan, respon, assurance, dan empati widyaiswara dalam kediklatan.

Dari data hasil penelitian, nilai tertinggi kepuasan layanan kediklatan widyaiswara dengan rerata skor 4,39 adalah empati widyaiswara saat pembelajaran. Selanjutnya skor 4,38 adalah jaminan, Skor 4,36 adalah tangible widyaiswara dalam kediklatan. Skor 4,31 adalah keandalan widyaiswara dalam kediklatan dan terendah dengan skor 4,30 adalah kemampuan widyaiswara dalam memberikan respon dalam kediklatan.

Skor rerata dari keseluruhan aspek layanan widyaiswara dalam layanan diklat teknis subtantif guru bimbingan dan konseling Madrasah Aliyah adalah 4,35. Skor tersebut setelah dikonsultasikan dengan kategori skala kepuasan layanan pada tabel 4, maka rerata kepuasan layanan termasuk dalam kategori sangat memuaskan $(4,30$ $-5,00)$.

Kesimpulannya, bahwa peserta diklat reguler Teknis Subtantif Guru Bimbingan dan Konseling Madrasah Aliyah tahun 2019 sangat puas terhadap pelayanan widyaiswara. Namun, beberapa sub aspek perlu ditingkatkan, yaitu daya responsive dan keandalan widyaiswara dalam layanan kediklatan.

Untuk memberikan gambaran yang lebih dalam, selanjutnya secara terinci kualitas layanan sebagai temuan tentang kepuasan layanan disajikan dalam bentuk grafik per aspek. Analisa data tingkat kepuasan layanan dilakukan dengan dikonsultasikan dengan skala kepuasan sebagai mana tabel 4 . a. Wujud/Tangible

Layanan Widyaiswara

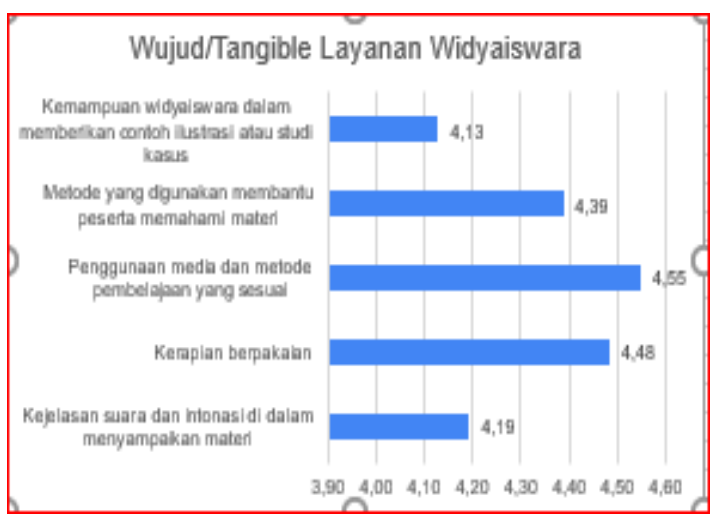

Grafik 5. Wujud/tangible layanan Widyaiswara

Dalam layanan kediklatan yang diberikan widyaiswara, dimensi ini adalah hal-hal terkait dengan kemampuan yang langsung dilakukan widyaiswara dalam pelatihan berupa penampilan widyaiswara, media pembelajaran yang digunakan dan kemampuan widyaiswara dalam memberikan contoh-contoh pembelajaran.

Dari data hasil penelitian, nilai tertinggi kepuasan layanan kediklatan yang diberikan widyaiswara dengan skor 4,55 adalah pada penggunaan media dan metode pembelajaran yang sesuai. Skor 4,48 adalah kerapian berpakaian, Skor 4,39 adalah metode yang digunakan membantu peserta memahami materi. Skor 4,19 adalah kejelasan suara dan intonasi dalam menyampaikan materi. Skor terendah 4,13 adalah kemampuan widyaiswara dalam memberikan ilustrasi atau contoh kasus.

Skor total dari aspek wujud atau tangible layanan diklat teknis subtantif guru bimbingan dan konseling Madrasah Aliyah adalah 
4,3. Skor ini setelah dikonsultasikan dengan skala kepuasan layanan pada tabel 4, termasuk dalam kategori sangat memuaskan $(4,30-5,00)$.

Kesimpulannya, bahwa peserta diklat reguler Teknis Subtantif Guru Bimbingan dan Konseling Madrasah Aliyah tahun 2019 sangat puas terhadap pelayanan widyaiswara dalam aspek wujud/tangibles. Subaspek yang perlu ditingkatkan adalah kejelasan suara dan intonasi serta kemampuan widyaiswara dalam memberikan ilustrasi dan contoh kasus.

b. Keandalan Layanan Widyaiswara (Reliability)

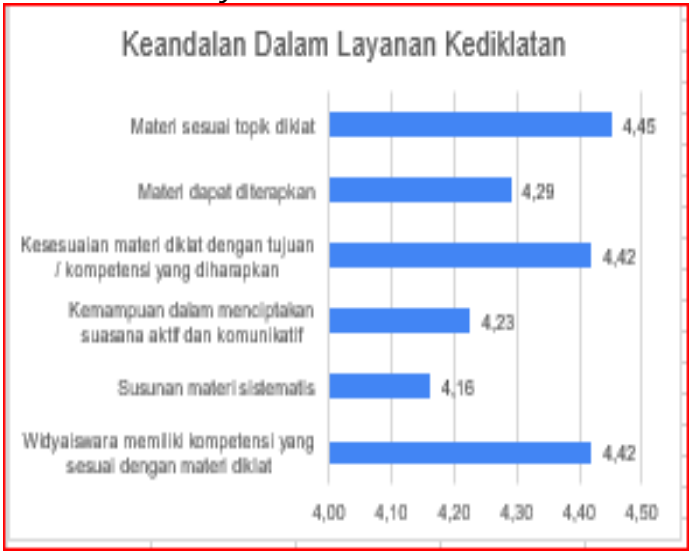

Grafik 6 Keandalan dalam layanan

Dari data hasil penelitian, nilai tertinggi kepuasan layanan kediklatan yang diberikan widyaiswara dengan skor 4,45 adalah pada materi sesuai topik diklat. Skor 4,42 adalah kesesuaian materi diklat dengan tujuan atau kompetensi yang diharapkan. Skor 4,42 adalah widyaiswara memiliki kompetensi yang sesuai dengan materi diklat. Skor 4,29 adalah materi dapat diterapkan. Skor 4,23 adalah kemampuan widyaiswara dalam menciptakan suasana aktif dan komunikatif. Skor terendah 4,16 adalah susunan materi sistematis.

Rerata skor keseluruan dari aspek keandalan widyaiswara dalam layanan diklat teknis subtantif guru bimbingan dan konseling Madrasah Aliyah adalah 4,3. Setelah dikonsultasikan dengan kategori skala kepuasan layanan pada tabel 4, skor ini termasuk dalam kategori sangat memuaskan $(4,30-5,00)$.

Kesimpulannya, bahwa peserta diklat reguler Teknis Subtantif Guru Bimbingan dan Konseling Madrasah Aliyah tahun 2019 sangat puas terhadap pelayanan widyaiswara pada aspek keandalan/ reliability. Sub-aspek yang perlu ditingkatkan adalah susunan materi yang sistematis dan menciptakan suasana aktif dan komunikatif dalam diklat.

C. Daya Respon Widyaiswara
(responsivess)

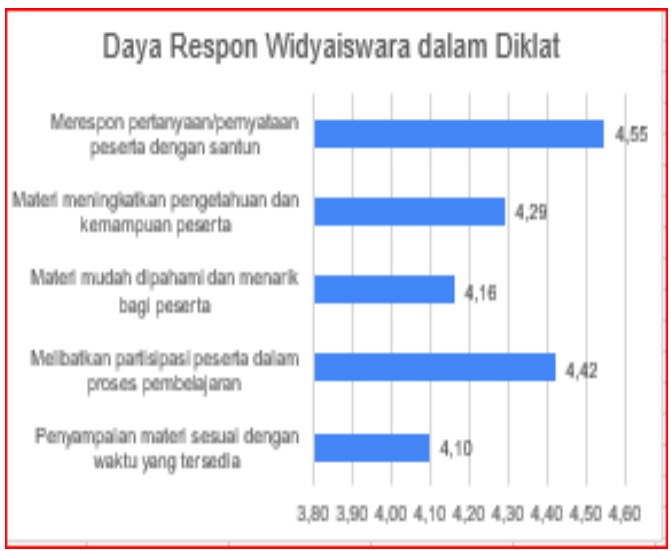

Grafik 7 Daya Respon Dalam Diklat

Dari data hasil penelitian, nilai tertinggi kepuasan layanan kediklatan yang diberikan widyaiswara dengan skor 4,55 adalah pada merespon pertanyaan peserta dengan santun. Skor 4,42 adalah melibatkan peserta dalam proses 
kediklatan. Skor 4,29 adalah materi meningkatkan pengetahuan dan kemampuan peserta diklat. Skor 4,16 adalah materi mudah dipahami dan menarik bagi peserta diklat. Skor terendah 4,10 adalah penyampaian materi sesuai dengan waktu yang tersedia.

Rerata skor keseluruhan dari aspek keandalan widyaiswara dalam layanan diklat teknis subtantif guru bimbingan dan konseling Madrasah Aliyah adalah 4,3. Setelah dikonsultasikan dengan kategori skala kepuasan layanan pada tabel 4, skor ini termasuk dalam kategori sangat memuaskan $(4,30-5,00)$.

Kesimpulannya, bahwa peserta diklat reguler Teknis Subtantif Guru Bimbingan dan Konseling Madrasah Aliyah tahun 2019 sangat puas terhadap pelayanan widyaiswara pada aspek daya respon/ responsiveness. Sub-aspek yang perlu ditingkatkan adalah penyampaian materi sesuai dengan waktu yang tersedia dan materi mudah dipahami dan menarik bagi peserta diklat.

d. Wujud Jaminan Layanan (Insurance)

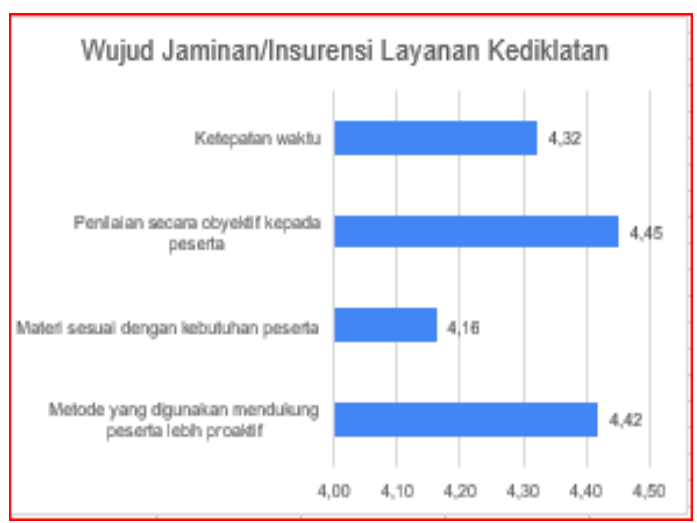

Grafik 8 Wujud Jaminan Layanan Diklat

Dari data hasil penelitian, nilai tertinggi kepuasan layanan kediklatan yang diberikan widyaiswara dengan skor 4,45 adalah pada penilaian secara obyektif kepada peserta. Skor 4,42 adalah metode yang digunakan mendukung peserta lebih proaktif dalam proses kediklatan. Skor 4,32 adalah ketepatan waktu diklat. Skor terendah 4,16 adalah materi sesuai dengan kebutuhan peserta diklat.

Rerata skor keseluruhan dari aspek keandalan widyaiswara dalam layanan diklat teknis subtantif guru bimbingan dan konseling Madrasah Aliyah adalah 4,3. Setelah dikonsultasikan dengan kategori skala kepuasan layanan pada tabel 4 , skor ini termasuk dalam kategori sangat memuaskan $(4,30-5,00)$.

Kesimpulannya, bahwa peserta diklat reguler Teknis Subtantif Guru Bimbingan dan Konseling Madrasah Aliyah tahun 2019 sangat puas terhadap pelayanan widyaiswara pada aspek wujud jaminan / insurance. Sub-aspek yang perlu ditingkatkan adalah materi sesuai dengan kebutuhan peserta diklat dan ketepatan waktu diklat.

e. Empati Layanan Diklat

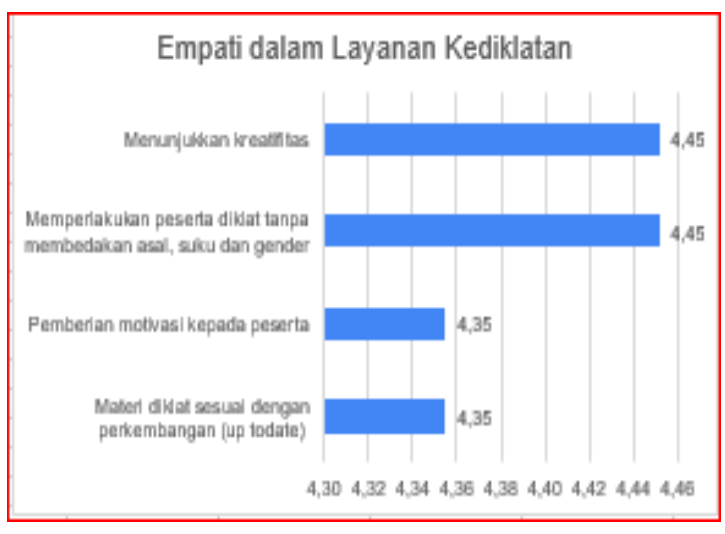

Grafik 9 Empati dalam Layanan Diklat 
Dari data hasil penelitian, nilai tertinggi kepuasan layanan kediklatan yang diberikan widyaiswara dengan skor 4,45 adalah pada dua (2) aspek, yaitu widyaiswara menunjukkan kreatifitas dan memperlakukan peserta diklat tanpa membedakan asal, suku dan gender. Skor 4,35 adalah pada dua (2) aspek, yaitu widyaiswara memberikan motivasi kepada peserta dan materi diklat sesuai dengan perkembangan (up to date).

Rerata skor keseluruhan dari aspek empati widyaiswara dalam layanan diklat teknis subtantif guru bimbingan dan konseling Madrasah Aliyah adalah 4,38. Setelah dikonsultasikan dengan kategori skala kepuasan layanan pada tabel 4, skor ini termasuk dalam kategori sangat memuaskan $(4,30-5,00)$.

Kesimpulannya, bahwa peserta diklat reguler Teknis Subtantif Guru Bimbingan dan Konseling Madrasah Aliyah tahun 2019 sangat puas terhadap pelayanan widyaiswara pada aspek empati. Sub-aspek yang perlu ditingkatkan adalah widyaiswara memberikan motivasi kepada peserta dan materi diklat sesuai dengan perkembangan ilmu pengetahuan dan kebutuhan peserta diklat.

\section{Pembahasan}

Hasil penelitian ini sesuai dengan penelitian terdahulu tentang adanya factor-faktor yang berpengaruh terhadap kepuasan layanan widyaiswara dalam penyelenggaraan diklat yaitu tangible yaitu penampilan serta kondisi pelayanan widyaiswara, keandalan layanan diklat yang akurat dan terpercaya, responsif atau bijaksana dalam memberikan layanan kepada peserta, adanya assuransi atau kemampuan melaksanakan tugas secara efektif yang menjamin kualitas diklat, dan empati berupa memberikan layanan mempribadi terhadap peserta diklat.

Untuk itu, Balai Diklat Keagamaan Surabaya perlu menaruh perhatian terhadap layanan pendidikan dan pelatihan khususnya masalah kepuasan peserta diklat, karena kepuasan peserta diklat merupakan indikasi layanan yang prima, berkualitas dan efektif dalam pencapaian tujuan diklat. Layanan yang memuaskan merupakan upaya mencapai kepuasan pelanggan melalui layanan produk/jasa yang berkualitas dengan efisien dan terprogram untuk memenangkan persaingan memperebutkan prestasi.

Balai Diklat perlu mengetahui kebutuhan dan keinginan pelanggan yang setiap saat berubah. Kepuasan pelanggan sangat tergantung pada harapan pelanggan, maka sebagai pemasok produk atau jasa kediklatan perlu mengetahui faktor-faktor yang mempengaruhi kepuasan layanan kediklatan untuk meningkatkan mutu layanan kediklatan dalam pengembangan sumberdaya manusia Kementerian Agama.

Dalam layanan kediklatan yang diberikan widyaiswara, dimensi kepuasan meliputi hal-hal terkait dengan kemampuan yang langsung dilakukan widyaiswara dalam pembelajaran yang berupa tangible, keandalan, respon, assuransi, dan empati widyaiswara dalam kediklatan.

Data hasil penelitian menunjukkan bahwa nilai tertinggi kepuasan layanan kediklatan widyaiswara adalah 
kemampuan widyaiswara dalam merespon pertanyaan yang diajukan peserta dengan santun. Aspek respon dengan santun ternyata merupakan kebutuhan peserta diklat, karena mereka sebagian besar adalah guru dan tenaga teknis pendidikan keagamaan yang mengedepankan nilai-nilai kesantunan.

Kesantunan layanan (politeness) merupakan perilaku yang diekspresikan dengan cara yang baik atau beretika dalam diklat. Kesantunan dalam layanan kediklatan termasuk didalamnya kesantunan berbahasa dengan menciptakan suasana interaksi menyenangkan, tidak mengancam dan ramah.

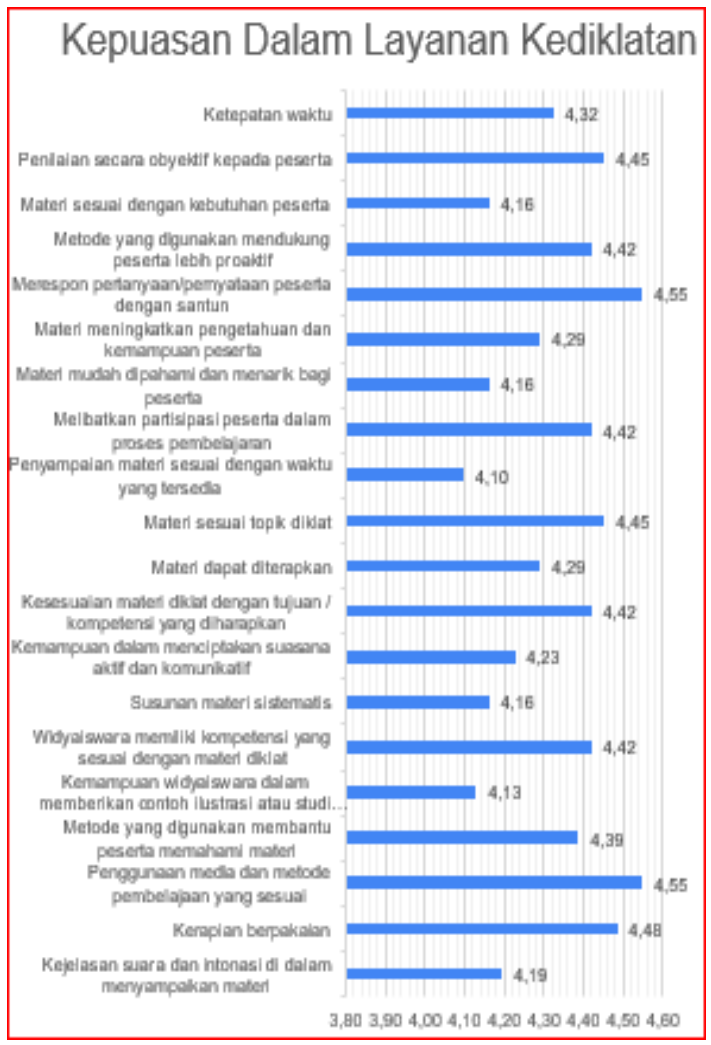

Grafik 10 Total skor Layanan Diklat

Dalam diklat widyaiswara diharapkan memahami kebutuhan peserta dalam berinteraksi atau berkomunikasi dengan 'muka'yang santun. Brown dan Levinson (1987) membedakan dua jenis 'muka', yaitu positive face, yang berarti menunjukkan solidaritas, dan negative face, yang menunjukkan hasrat untuk tidak diganggu dalam tindakannya. Kesantunan yang diperlukan saat kita berinteraksi dengan orang lain, yaitu positive politeness, yang ditandai dengan penggunaan bahasa informal dan menawarkan pertemanan.

Data hasil penelitian juga menunjukkan bahwa nilai tertinggi kepuasan layanan widyaiswara adalah penggunaan media pembelajaran dan metode yang sesuai kebutuhan diklat. Media pembelajaran dapat membantu untuk meningkatkan interaksi diklat, sehingga proses kediklatan akan lebih berpusat pada pembelajar, yang menjadikan peserta aktif berperanserta dalam pembelajaran. Selain itu, penggunaan media dalam bentuk audio visual, komputer, atau media-media yang lain dalam proses kediklatan dapat membantu peserta diklat menguasai materi diklat.

Dalam andragogi (pembelajaran untuk orang dewasa), sebagian besar pembelajar memiliki tanggunggung jawab serta beberapa situasi yang dapat mempengaruhi proses belajar. Pada umumnya pembelajar dewasa memiliki motivasi yang tinggi dan berorientasi pada tugas yang ada pada dirinya (Cercone, 2008).

Sebagai lembaga kediklatan pemerintah, maka selayaknya balai diklat menaruh perhatian terhadap masalah kepuasan layanan masyarakat terhadap kediklatan. Dimensi kualitas pelayanan yang telah disebutkan di atas, harus diramu dengan baik agar lembaga dapat mencapai tujuan kediklatan melalui kualitas pelayanan yang tepat. 
Berbagai kompetensi kediklatan yang harus dimiliki widyaiswara tentu semuanya harus dikembangkan, mencakup tangible, keandalan, respon, assuransi, dan empati widyaiswara dalam kediklatan.

\section{PENUTUP}

\section{Simpulan}

Layanan kediklatan yang dilakukan Widyaiswara Balai Diklat Keagamaan Surabaya telah memenuhi aspek aspek tangible (penampilan fisik serta kondisi pelayanan widyaiswara), keandalan (kompetensi diklat yang dijanjikan dengan akurat dan terpercaya sesuai harapan peserta), respon (bijaksana memberikan layanan cepat kepada peserta), assuransi (kemampuan melaksanakan tugas secara spontan yang menjamin kualitas diklat), dan empati (memberikan perhatian individual dan memahami peserta diklat).

Tingkat kepuasan masih-masing faktor layanan yang berbeda-beda menunjukkan beragamnya cara dan widyaiswara dalam menuikapi keinginan peserta diklat, juga beragamnya kebutuhan peserta. Oleh karena itu, penting bagi widyaiswara secara terus menerus melakukan inovasi layanan kediklatan.

Kualitas keseluruhan aspek layanan kediklatan yang dilakukan widyaiswara telah menunjukkan skala sangat memuaskan. Urutan kualitas paling memuaskan adalah dari dimensi empati, assuransi, tangible, keandalan, dan respon widyaiswara terhadap peserta diklat.

\section{Rekomendasi}

Balai Diklat perlu memberikan dukungan untuk meningkatkan kualitas widyaiswara dalam layanan kediklatan yang semakin berkualitas dan memuaskan peserta diklat, sehingga tujuan pengembangan sumber daya manusia dapat terwujud secara optimal.

Widyaiswara sebagai pelaku pembelajaran dan kediklatan perlu melakukan pengembangan kompetensinya secara terus menerus sesuai harapan peserta diklat.

Penelitian ini merupakan survei yang terbatas, perlu dilakukan peneliti lain melihat faktor-faktor lain yang dapat memberikan gambaran yang lebih luas tentang layanan diklat.

\section{DAFTAR PUSTAKA}

Ariani, D. (2009). Manajemen Operasi Jasa (Cetakan Pertama ed.). Yogyakarta: Graha Ilmu.

Brown, P., \& Levinson, S. C. (1987). Politeness: Some Universals in Language Usage. Cambridge: Cambridge University Press.

Cadotte, E., Woodruff, R., \& Jenkins, R. (1987). Expectations and Norms in Models of Consemer Satisfaction. Journal of Marketing Research, 24(3), 305-314. doi:https://doi.org/10.2307/3151641 
Cercone, K. (2008). Characteristics of Adult Learners with Implications for Online Learning Design. AACE Journal, 16(2), 137-159. Diambil kembali dari https://www.learntechlib.org/primary/p/24286/

Day, R. (1984). Modeling Choices Among Alternative Responses to Dissatisfaction. Dalam T. Kinnear (Penyunt.), Advances in Consumer Research (Vol. 11, hal. 496-499). Diambil kembali dari http://acrwebsite.org/volumes/5934/volumes/v11/NA-11

Fornell, C. (1992). A National Customer Satisfaction Barometer: The Swedish Experience. Journal of Marketing, 56, 6-21. doi:https://doi.org/10.2307/1252129

Keller, P. K. (2008). Manajemen Pemasaran. Jakarta: Erlangga.

Lupiyoadi, \& Hamdani. (2006). Manajemen Pemasaran Jasa. Edisi Kedua. Jakarta: Penerbit Salemba Empat.

Nuraini. (2018). Tingkat Kepuasan Peserta Terhadap Kualitas Pelayanan Widyaiswara Pada Diklat Teknis Substantif Publikasi Ilmiah bagi Guru Mata Pelajaran Agama MTs Angkatan III. Andragogi Jurnal Diklat Teknis Pendidikan dan Keagamaan, 6(1), 168-186. doi:https://doi.org/10.36052/andragogi.v6i1.53

Schiffman, \& Kanuk. (2004). Perilaku Konsumen Edisi 7. Jakarta: Prentice Hall. 